AGNIESZKA CYBAL-MICHALSKA

Uniwersytet im. Adama Mickiewicza w Poznaniu

\title{
SCHOLAR IN THE SPECTACLE OF PARAMETRIZATION - BETWEEN AUTHENTICITY AND GAME OF APPEARANCES
}

The ability to compete seems to be gaining importance, becoming an element of mission and vision of the university, and yet "for centuries the academic tradition has been shaped according to non-codified rules of the game"1, which relied on such categories as studies, education, seeking for the truth, academic freedom and service for society. The neoliberal discourse, which is clearly visible in the higher education system, raises the problem of discrepancies between the principles of the traditionally understood academic mission and the principles of the market. In this context, it is worth asking the question whether easement towards science can be identified with scienctometrics, i.e. parameterization in the form in which we know it, where at least two indicators are subjective, namely: the type of criteria and their significance? And then we have to ask whether the propagation of parameterization principles, which is self-perpetuating, doesn't mean the lack of possibility to go beyond the borders of the parametrized world that we have begun to accept and in which we have started to play our roles ${ }^{2}$ ?

For the purpose of the subject I am interested in, I will refer to the metaphor of theatre, i.e. the theatre of parametrization reality in which we, the people of science, participate. The category US is supposed to emphasize in particular the communal character of the space of the performance in question. Our presence on the stage in relations with others co-creates the space of parameterization. At the same time, it seems to reflect K.G. Jung's thesis that " $M E$ really needs $U S$ in order to be oneself"'. Paraphrasing the arguments of A. MacIntyre and M. Sandel,

\footnotetext{
${ }^{1}$ T. Szulc, Uniwersytet i edukacja XXI wieku, [w:] Misja i stużebność uniwersytetu $w$ XXI wieku, red. J. Woźnicki, Warszawa 2013, s. 17.

2 The issues addressed in the article were also mentioned by the author in the text entitled: Naukowiec w parametryzacyjnym spektaklu - między autentycznościa a gra pozorów, „Humanior. Internet Journal" 2016, $\mathrm{nr} 4(16)$.

${ }^{3}$ After Ch. Handy, Głód ducha, Wrocław 1999, s. 108.
} 
one can say that the parametric history of a person's life is interwoven into the history of "his/her" parametric community, which defines "him/her"4. But there is a kind of doubt that requires us to ask a question about the quality of communal life, about the space for building a subjective bond and thinking in terms of US. Is it authentic, based on the ethos of science, the search for truth? It is an element of a broader question posed by Z. Melosik whether the university as a "temple of wisdom', a 'majestic symbol of Truth and Knowledge' will survive the passage of time?"5 And another question has been asked by T. Szulc, i.e. if "today's distrustful $<<$ Ivory Towers $>>$ will be able to embrace other new challenges and combine their universal mission with the pragmatism of commercial activity?" ${ }^{\prime 6}$ Or is the US space distorted? We have been included in this parameterization game, and like a Baumanian player, it doesn't matter what card you get, but it matters how you play it; in a nutshell, you should play to win. The role of a scholar is seen in terms of their "market value". Does the scholar, who becomes a provider of publication with regard to the parameterization needs, genuinely play his role as a researcher and discoverer of the scientific truth? Thus, with some reservations, we can speak of a communal character. On the other hand, the parameterization space "arises during co-presence and as a result of co-presence"

Theatrical space for building relations of "co-presence" is not free from our need for recognition, individuality, uniqueness and being the best at the top of the parametric ranking by playing well the role of a "scholar", where "accentuated facts make their appearance in what we have called $<<$ the front region (stage) $>>$ " . In the metaphorical sense adopted by me, the word "play" is not pejorative. After A. Augustynowicz we can say "I am as good as I can perform my role", in a given time and place - for the benefit of the subject matter at hand it will be the parametrized context of time and place which will attest to the quality of the issue. Thus, in order to be a scientist, an architect of independent, in-depth scientific thought, one has to professionally play one's role in subsequent acts of our professional scholarly biography, in which parameterization is the context and the number of points is the standard. Acts are spaces of our scientific activity, which by grasping the "difference" between others and each other in time, as emphasized by P. Ricoeur ${ }^{10}$, allow

\footnotetext{
${ }^{4}$ After M. Środa, Indywidualizm i jego krytycy, Warszawa 2003, s. 195.

5 See: Z. Melosik, Uniwersytet i spoleczeństwo, Kraków 2009.

${ }^{6}$ T. Szulc, dz. cyt., s. 17.

7 J. Szacki, in: The Presentation of Self in Evereyday Life, E. Goffman, New York 1959, s. 76.

8 Tamże, s. 78-79.

9 A. Augustynowicz, Być czy grać, role i maski w ksztaltowaniu przestrzeni między ludźmi, Brejk II, s. 5 (typescript).

${ }^{10}$ After Z. Bauman, Tożsamość - jaka była, jest i po co?, [w:] Wokót problemów tożsamości, red. A. Jawłowska, Warszawa 2001, s. 11.
} 
us to exist, crystallize our mage, define ourselves and be recognized as a scholar. Self-identification as a researcher is therefore associated with a particular emphasis on the difference with respect to the "other" and emphasizing the process-oriented nature of identity with respect to oneself in a temporal perspective. The question then arises as to whether and to what extent parameterization is its reflection and realization. There is no doubt that we have become actors of the parameterization drama, which leads us to ask questions about the meaning of our participation in the drama in which we have been cast and we have come to play.

The first experience of the theatre with the spectacle of parameterization, in which we are to play our roles (the performance that allows us to capture the sense of the difference), occurred with the appearance of the State Committee for Scientific Research established by law of 12 January 1991. The parametric evaluation and the resulting categorisation of institutions was carried out once every four years, in the first full year of the Committee's four-year term of office, on the basis of the documented scientific research and development results obtained in the previous four full years.

Parametric theatre in its essence has a communal character. In this context, it should be noted that in the scientific dimension of our activity we are bound by a place with a clear multiplication of the circles of this activity: national, European and world space for practicing science. Also we are bound by time as parameterization covers certain years: 2005-2009, 2009-2012, 2013-2016. While emphasizing the temporal dimension, it should also be accentuated that "parametrization" spectacle is performed in the present time. However, as regards time, it is still possible to indicate a parametric evaluation of the first and each subsequent one, which is changed in terms of the content of evaluation criteria and indicators. Undoubtedly, we are bound by action. The game is about a place on the stage in order to be in the highest possible category of scientific activity. In fact, we care about recognising our value (as a university, faculty, institute, department, company, research and teaching staff) determined by the achieved ranking position defined mainly by the number (and not necessarily the quality) of highly ranked publications. It is sometimes impossible to give in to the impression that a significant output starts to be confused with a one "signified" by a high number of points. It is difficult to defend the argument that the quality of an article is evidenced only by the place of its publication, or only by the number of quotations. Undoubtedly, we care about the recognition of our own value. And if one asks a question before whom? The answer will be: before others with whom the scholar enters into relations at different levels of the parametric game, in community with others and for himself and before himself. We are bound by sense, or rather searching and discovering it. It makes sense to search, but also to discover the truth about the growing commercialization of publishing activity and discover in the subsequent 
acts of the parametrization drama the truth of the stage performance before others with whom we enter into relations, in community with others, and the truth about ourselves. We are bound by the stage. What binds individual universities, scientific institutions and each parameterization actor is the stage on which the drama takes place, and what divides them is the place on it, in the context of the location between universities, within universities, within faculties, within institutions, within departments. We play on the "stage" of the space determined: a) by the scientific discipline, b) in the area of the adopted indicators and criteria of the substantive content and the type of survey (a survey common for humanities and social sciences, a survey common for sciences, life sciences and engineering, a survey for art disciplines and their artistic fields). We are bound by the rules of the game. In parametrization theatre, a view of scientific activity takes place through the prism of the number of points. In the general rules and regulations we read that the parametric evaluation is expressed by the number of $\mathrm{R}$ points awarded to the institution within the defined criteria.

As A. Augustynowicz points out, the theatre is a "mimetic art". From masters and other actors of the parametric spectacle we take over their expression. It can hopefully contain developmental potential when we learn to "live" our role, focusing on the highest quality scientific discourse. It is to a large extent a focus on the creative process and the service of science in search of the scientific truth. However, it also may not contain a developmental potential when one tries to wear a mask of a scholar because their publication activity is not always innovative, which does not necessarily mean the lack of parameterization success because "publication avatars" can function very well in the space of highly ranked publications. And this is "backstage activity", the existence of a secondary realm of hidden facts, where "the impressions fostered by the performance is knowingly contradicted as a matter of course (...). It is here that the illusions and impressions are openly constructed. Here, the props (....) are arranged in such a way that a graceful whole is created from stage behaviours and roles"11. This is the orientation to the parameterization "result", but in a speculative sense.

Acting is not a transformation and total immersion into someone imagined, someone alien. "It's not like wearing a mask while playing. On the contrary - we take it off"' ${ }^{\prime 2}$. In this way you play the incarnation in someone you carry somewhere in yourself. In this context the character of the artist, i.e. an actor, is quite significant. As Z. Bauman emphasizes, "it is he who chooses among the options provided by fate (...) and if a person is able to stick to a relatively straight line,

\footnotetext{
${ }^{11}$ E. Goffman, The Presentation of Self In Evereyday Life, New York 1959, s. 69-70.

12 M. Kukawski, Women we love - Agnieszka Grochowska, "Film" 2011, s. 141.
} 


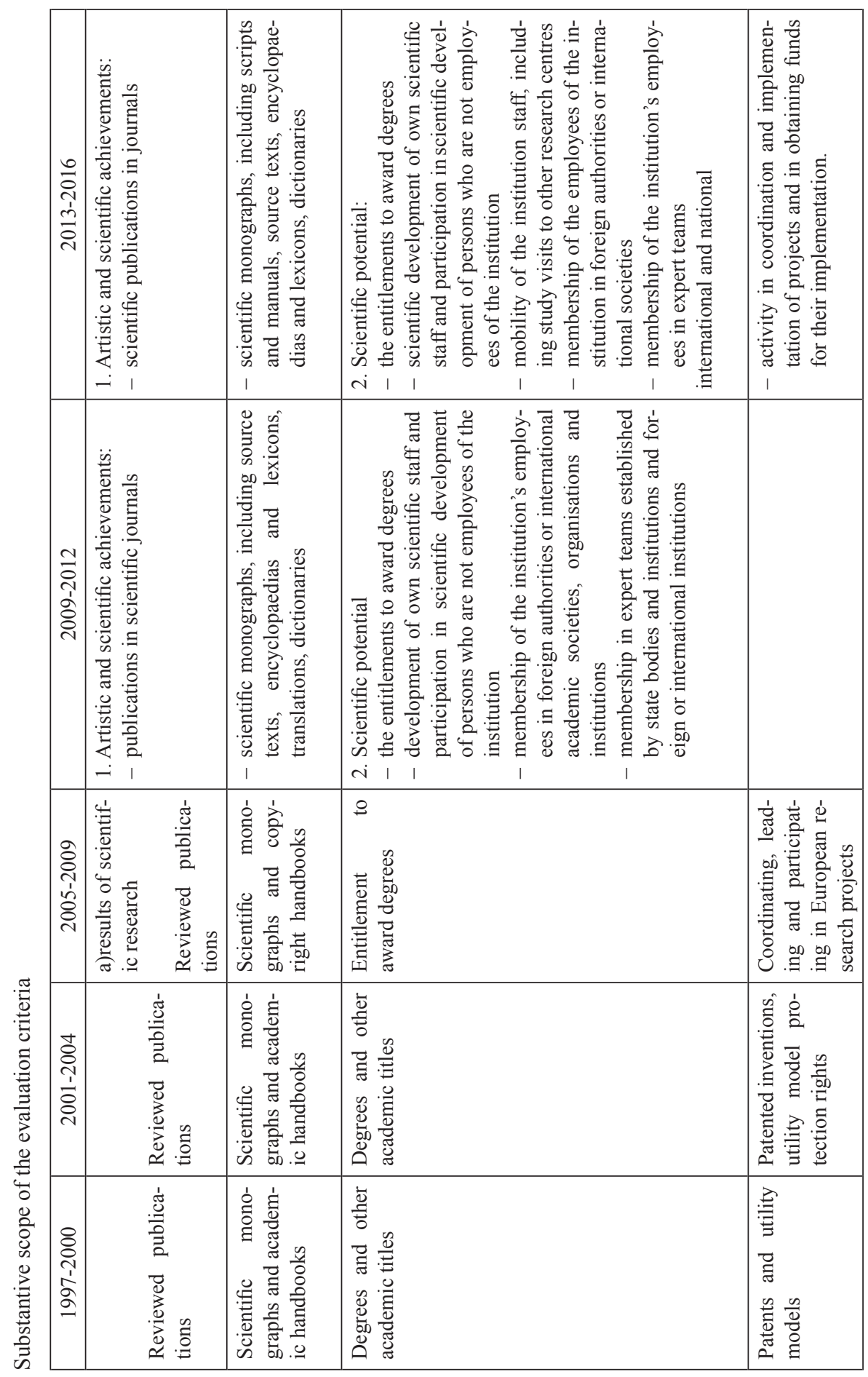




\begin{tabular}{|c|c|c|}
\hline 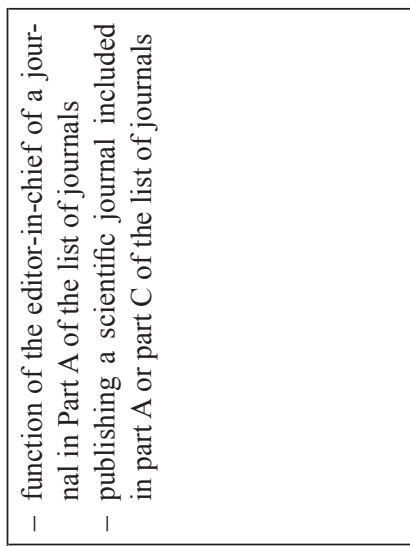 & 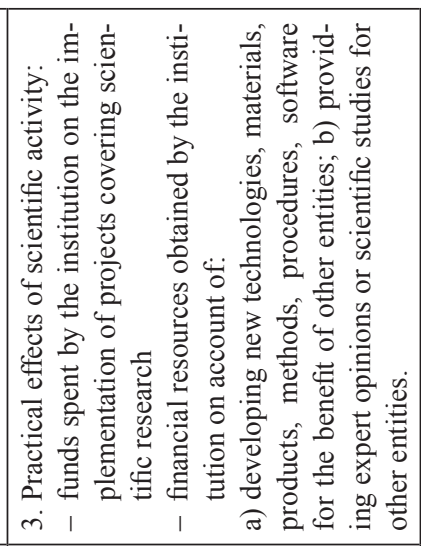 & 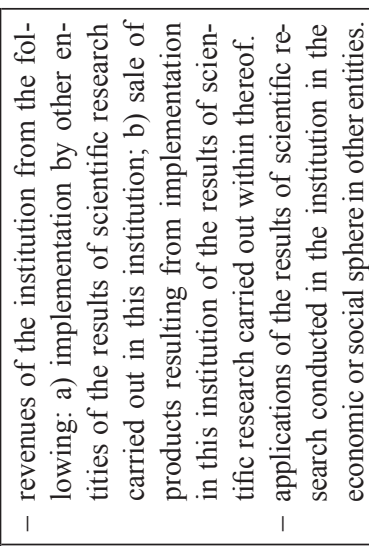 \\
\hline 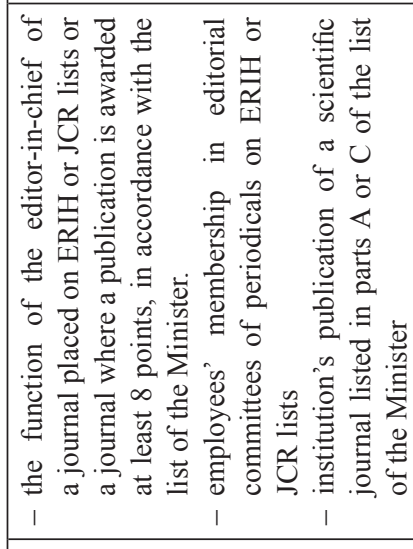 & 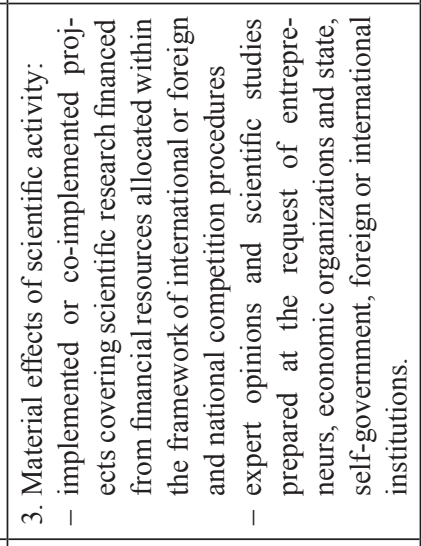 & 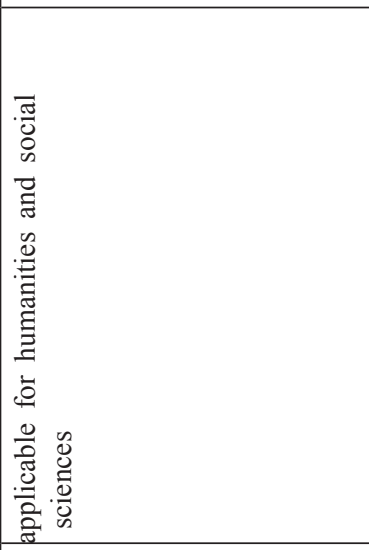 \\
\hline 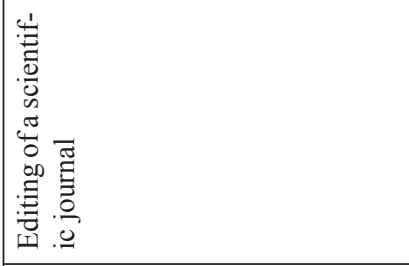 & 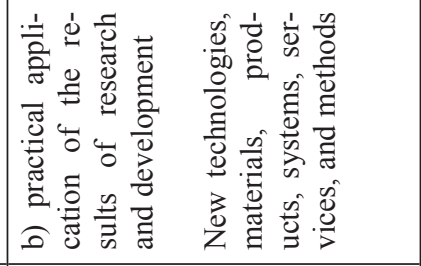 & 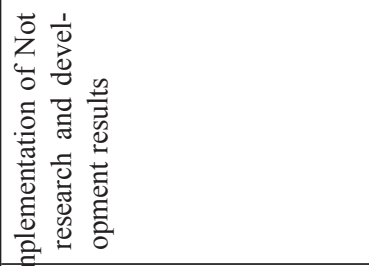 \\
\hline  & 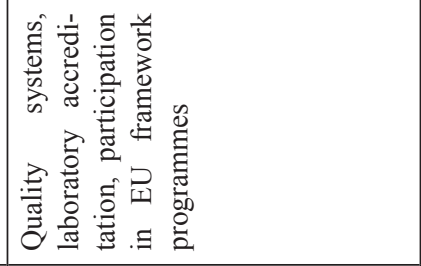 & 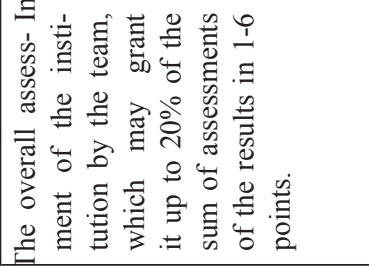 \\
\hline 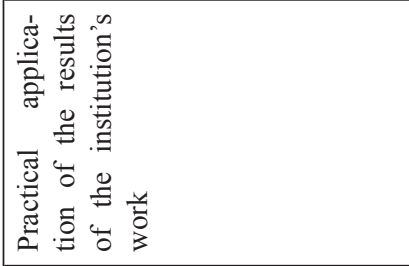 & 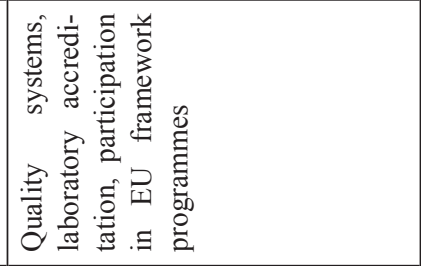 & 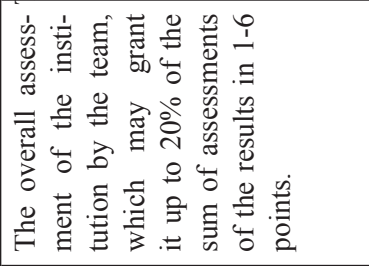 \\
\hline
\end{tabular}







then the character is a merit, not fate a weakness or an oversight"13. This draws attention to the need to develop and update the sense of agency, and therefore the conviction of "the possibility of influencing the course of events" 14 and the surrounding reality, as well as the sense of subjectivity, i.e. that one is "a creator and agent of events which result from one's own preferences (...) and it is accompanied by readiness to take the responsibility for agency"15.

In the theatre of parametrization, even before the curtain is raised, even before the confrontation with the audience, an uninvited "guest" can appear, i.e. stage fright which often "does not give in to the artist's control and will not listen to his will"16. This is the anxiety related to the following: a) meeting with others in this parametric space at different levels: university, faculty, institute, company, b) very often the dimension of the other as it is difficult to anticipate what truth will be released during this meeting on the stage of parametric theatre, c) an expression of fear of discovering the truth about oneself, which undoubtedly is facilitated by creating internal rankings of departments, among others.

A scientist present in the parameterization space may sometimes be tempted to separate himself from the context of " $U S$ " in order to emphasize his uniqueness, individuality, separateness when the individual "parameterization" success (measured by the number of points obtained in highly ranked journals) is significant, thus determining better self-assessment and the sense of self-esteem. There may also be the opposite situation when an individual who is not successful in "parameterization" is not interested in distinguishing himself from others because he does not want to feel responsible for this parameterization space, regardless of whether it is a matter of satisfaction or dissatisfaction for the community. The individual will feel uncomfortable and in the latter case also feel guilty. As E. Goffman puts it "when one's activity occurs in the presence of other persons, some aspects of the activity are expressively accentuated, and other aspects, which might discredit the fostered impression are suppressed"17. The division into the stage and backstage is significant. "It is clear that accentuated facts make their appearance in what we have called $<<$ the front region (stage) $>>$ "18 - Goffman adds.

In the parameterization we uncover (remove) the mask of the "scientist". Our other masks, such as: "educator", "lecturer", "organizer of scientific life"

\footnotetext{
${ }^{13}$ Z. Bauman, Między chwila a pięknem. O sztuce w rozpędzonym świecie, Officyna, Łódź 2010, s. 72.

${ }_{14}$ T. Zysk, Orientacja prorozwojowa, [w:] Orientacje społeczne jako element mentalności, red. J. Reykowski, K. Skarżyńska, M. Ziółkowski, Poznań 1990, s. 197.

${ }_{15}$ M. Czerepaniak-Walczak, Między dostosowaniem a zmianq̨. Elementy emancypacyjnej teorii edukacji, Wydawnictwo Naukowe US, Szczecin 1994, s. 106.

${ }^{16}$ Z. Bauman, Między chwila ... dz. cyt., s. 72.

${ }^{17}$ E. Goffman., dz. cyt., s. 79.

18 Tamże.
} 
are names which are used to distinguish between other roles because, as A. Augustynowicz emphasizes, "the boundaries of the roles are determined by situations" 19 - in the discussed context the situation of parametric juxtaposition of our scientific work. In this context, it is worth asking a question: What does it mean, then, that I am a scholar in a parametric spectacle? How not to fall out of the role? Your existence is determined by the manner in which you can create your role in a certain period of time, usually in four-year periods of parametrization evaluation. In the sense we are interested in, one can say that one is "valuable in terms of parameterization", if one is able to obtain the highest possible number of points in a given period of time. However, "playing a role assumes the effort of putting energy into the co-creation of space" 20 . It is a scientific entity that is evaluated, not an individual. So this energy is invested by everyone who has been cast in the parameterization spectacle. Entities are evaluated and categorized in groups of homogeneous institutions due to discipline on the basis of the final efficiency index obtained.

\begin{tabular}{|l|l|l|c|c|}
\hline \multicolumn{1}{|c|}{$1997-2000$} & \multicolumn{1}{|c|}{$2001-2004$} & \multicolumn{1}{|c|}{$2005-2009$} & \multicolumn{1}{c|}{$2009-2012$} & 2013-2016 \\
\hline Kat.1-5 & Kat.1-5 & Kat. 1 - kat. A-max.30\% & Kat. A, A+, B, C & Kat. A, A+, B, C \\
\hline Kat.1 - $20 \%$ & Kat.1 - $20 \%$ & $\begin{array}{l}\text { Kat. 2-3 - kat. B - max. } \\
50 \% \text { A+B }\end{array}$ & & \\
\hline Kat 2 -30\% & Kat 2 -30\% & Kat. 4-5 - kat. C & & \\
\hline $\begin{array}{l}\text { Below the thre- } \\
\text { shold }- \text { no cat. }\end{array}$ & $\begin{array}{l}\text { Below the thre- } \\
\text { shold }- \text { no cat. }\end{array}$ & & & \\
\hline
\end{tabular}

It should be noted that not everyone was invited to play on the stage of the parametric theatre. The voice and the role was mainly given to people for whom the institution is the primary place of work. It is this group that is in the main cast and these actors are allowed to play their roles in the parametrization performance. It is also worth emphasizing that by accepting parameterization criteria as main actors, we allow the Ministry of Science and Higher Education, the competent committee of the Council of Science and the National Committee for Scientific Research to assume the role of a "director", after obtaining the consent of the Committee (19972000, 2001-2004) or the Committee for the Evaluation of Scientific Research Institutions. The director's activity and expectations cause that during stage readings and rehearsals, attention is focused not so much on possibilities (where you can publish), but rather on publication obligations (where you should publish the text, paying

\footnotetext{
19 A. Augustynowicz, dz. cyt.

20 Tamże.
} 
attention mainly to the parameterization interest). It is in this space of meeting in a vertical and interdependence system that the "drama" takes place, testifying to the quality of the parameterization scenario and the question, and the fear of its meaning for social sciences and humanities. The discussion in various forums touches upon this problem, which can be expressed in the question: Does the parameterization of humanists satisfy us by revealing its meaning, even more tangible post factum, when we are aware of what's behind us (while being aware of what Bauman points out, inspired by Leslie Hartley's novel The Go-Between, namely: "The past is a foreign country where things happen differently"21)? Or have we abandoned our expectations and imaginations, possibilities and duties completely and we are stuck in this reality "in spite of the open door"? The parameterization past in its historical form will remain the same for us forever. Following in the footsteps of Z. Bauman one can "while listening to the past, talk to the future"22. This means drawing conclusions, thinking twice and reflecting responsibly on meaning and, in its context, on the criteria for subsequent evaluation questionnaires. This means perhaps, to remind Luis Bunuel's work ${ }^{23}$, breaking free from a form of "delusional hell" where any obstacles are non-existent. In an individual dimension, this may mean reflection on style of the role played before taking up the next one: similar but not the same, the role which will be performed differently.

To sum up, it should be emphasized that the parameterization space involves both winners and losers, taking as a point of reference the aspirations to participate in the parametization game and there appears to be no liberation from the repertoire of the "parameterization drama". Awareness of the inevitability of the game leads to the recognition that the ability to read one's role well consists in, as Bauman puts it, recognizing, realizing and accepting "our not-by-us-chosen, but day after day by-us-reproduced, human way of being" 24 into which the theatrical character of parametric reality is written. However, it does not mean that "we should accept this inevitability" 25 . The essence is to focus on updating the potential within us and to define our relations (including possible relations) with this parametric reality. In theatrical metaphors we can also point to the need for a clear distinction between the quality of the performance and the performed quality, because according to Eliade, "presented banality can generate criticism if it is not entangled in the banality of the performance" 26 .

${ }^{21}$ Z. Bauman, Między chwila ... dz. cyt., s. 79.

${ }^{22}$ Tamże.

${ }^{23}$ Reference to the film directed by Luis Bunuel from 1962 entitled The Extermination Angel.

${ }^{24}$ Z. Bauman, Między chwila... dz. cyt., s. 84.

25 Tamże.

${ }^{26}$ L. Witkowski, Teoretyczny stownik interdyscyplinarny nowej generacji dla pedagogiki jako dyscypliny metahumanistycznej, 1995, s. 5 (typescript made available at LSMP, paperbound edition). 


\section{REFERENCES}

Augustynowicz A., Być czy grać, role i maski w kształtowaniu przestrzeni między ludźmi, Brejk II (maszynopis).

Bauman. Z., Tożsamość - jaka była, jest i po co?, [w:] Wokót problemów tożsamości, red. A. Jawłowska, Wydawnictwo LTW, Warszawa 2001.

Bauman Z., Między chwila a pięknem. O sztuce w rozpędzonym świecie, Officyna, Łódź 2010.

Czerepaniak-Walczak M., Między dostosowaniem a zmiana. Elementy emancypacyjnej teorii edukacji, Wydawnictwo Naukowe US, Szczecin 1994.

Goffman E., The Presentation of Self In Evereyday Life, Doubleday: Garden City, New York 1959.

Handy Ch., Gtód ducha, Wydawnictwo Dolnośląskie, Wrocław 1999.

Kukawski M., Women we love - Agnieszka Grochowska, „Film” 2011, s. 141.

Melosik Z., Uniwersytet i społeczeństwo. Dyskursy wolności wiedzy i władzy, Oficyna Wydawnicza „Impuls”, Kraków 2009.

Szulc T., Uniwersytet i edukacja XXI wieku, [w:] Misja i stużebność uniwersytetu w XXI wieku, red. J. Woźnicki, Oficyna Wydawnicza Politechniki Warszawskiej, Warszawa 2013.

Środa M., Indywidualizm i jego krytycy: współczesne spory między liberałami, komunitarianami i feministkami na temat podmiotu, wspólnoty i ptci, Fundacja „Aletheia”, Warszawa 2003.

Witkowski L., Teoretyczny stownik interdyscyplinarny nowej generacji dla pedagogiki jako dyscypliny metahumanistycznej, Materiał roboczy do wykładu na XI Letniej Szkole Młodych Pedagogów, Toruń, s. 32.

Zysk T., Orientacja prorozwojowa, [w:] Orientacje spoleczne jako element mentalności, red. J. Reykowski, K. Skarżyńska, M. Ziółkowski, Wydawnictwo „Nakom”, Poznań 1990.

Author: Agnieszka Cybal - Michalska

Title: Scholar in the spectacle of parametrization - between authenticity and game of appearances

Keywords: parametrization, theater of the reality of parametrization, stage truth, role, result of parametrization

Discipline: Pedagogics

Language: English

Document type: Article

\section{Summary}

By referring to the metaphor of the theater - the theater of the reality of parametrization in which we the people of science participate - the author is wondering whether the servitude towards science can be identified with scientometrics, i.e., parametrization in the form that is known to us, where at least two of the indicators are subjective, namely: the type of the criteria and their weight. In the article, the emphasis is placed on the theatrical space of construction of the relation of "co-presence" which is not free from our need for recognition, individuality, uniqueness and being the best, at the top of the ranking of parametrization, "skillfully" playing our role of the "scientist" on the stage, which connects but also divides because of that, i.e. the place occupied on that stage. The acts are the spaces of our scientific activity, which - by capturing the "difference" in relation to others and the "difference" in relation to ourselves in time - allow us to be, to crystallize our image, to further define ourselves and to be recognizable in the role of a scientist in a reality that was not chosen by us, but is implemented according to codified rules of the game. 